\title{
Sustainability development consciousness and behavior of Thais: The effects on quality of life and happiness
}

\author{
Pratoom Rerkklang* \\ National Institute of Development Administration, Bangkok, Thailand
}

\author{
Keywords \\ Sustainability perception \\ Sustainability consciousness \\ Sustainable behavior \\ Quality of life \\ Happiness
}

Received: 8 December 2017

Accepted: 5 January 2018

Published: 13 February

\begin{abstract}
This research's aims are the following: 1) To study sustainability development perceptions, consciousness, behavior, including sufBiciency economy behavior, religiosity, family relation, quality of life, and happiness of Thais; 2) To study the relationship between sustainability development perceptions, consciousness, behavior, sufbiciency economy behavior, religiosity, family relation, quality of life, and happiness of Thais; 3) To study effects of sustainability development perceptions, consciousness, behavior, including sufBiciency economy behavior, religiosity, and family relation on the quality of life and happiness of Thais. This research used a survey design to study Thais nationwide. The sample was composed of 1,517 Thais from 5 central, eastern, northern, and southern and Bangkok regions. The sample was sampled by proportional quota. Research data were collected by questionnaires in which reliability was in the range from .889 to .968 . Data were computerized and analyzed by the Statistical Package Software. The research results found that sustainability development perception affected sustainable development consciousness, behavior, sufBiciency economy behavior, religiosity, family relation, quality of life, and happiness. There was a positive correlation between all variables. Sustainability development behavior affected the quality of life and happiness when controlling sustainability development perception, sufBiciency economy behavior, religiosity, and family relation. The Binding implies that the Thai government, business, and educational organizations should promote perception, consciousness, and behavior on sustainable development for the growth of nations.
\end{abstract}

(C) 2018 The Author(s). Published by TAF Publishing

\section{INTRODUCTION}

The most urgent priority and core development agenda of international community is sustainability development. Thailand, as one of the members of United Nations, also set the sustainability development to be an objective of national development plan. The current 12th National Economic and Social Development Plan starts on 1 October 2016 and will continue until 30 September 2021. The 12th Plan was worked out in accordance with the 20-year national strategy, 2017-2036. The Plan will be followed as a shared value by the Thai people, guiding the transformation to a new national management system, based on the goals of efficiency, quality of life, and sustainability. Besides, the plan is geared to reduce income disparity and poverty, strengthen the Thailand's economy and enhance the country's competitiveness, promote natural capital and environmental quality, and further boost the confidence of Thailand in the international community.

The 12th plan consists of 10 strategies for national development. In the first strategy, human capital will be enhanced and its potential will be developed. The second strategy seeks to ensure fairness and reduce social disparities. The third involves the strengthening of Thailand's economy on a sustainable basis (Pathumporn \& Nakapaksin, 2015; Rex, Yetunde, Grace, \& Pearl, 2017). The fourth strategy involves green growth. The fifth strategy aims to promote national stability, and the sixth one to combat corruption and promote good governance in Thai society. The seventh strategy involves infrastructure and logistics development. The eighth strategy seeks to develop science, technology, research, and innovation. The ninth strategy calls for urban and economic zone development and the tenth strategy involves international cooperation for development (The Government Public Relations Department, 2016).

\footnotetext{
${ }^{*}$ Corresponding author: Pratoom Rerkklang

†Email: pratoom.rerkklang@gmail.com
} 


\section{Objectives}

This research aims to study as below:

1) To study sustainability development perceptions, consciousness, behavior, including sufficiency economy behavior, religiosity, family relation, quality of life, and happiness of Thais.

2) To study the correlation among sustainability development perceptions, consciousness, behavior, including sufficiency economy behavior, religiosity, family relation, quality of life, and happiness of Thais.

3) To study the effect of sustainability development perceptions, consciousness, behavior, including sufficiency economy behavior, religiosity, and family relation on the quality of life and happiness of Thais.

\section{Significance of the Study}

The main purpose of this study is to evaluate sustainability development consciousness and behaviors of Thais and the effects of sustainability development consciousness and behaviors on well-being and happiness. Other variables that are evident from previous research results showed relationship with well-being and happiness which were sufficiency economy behavior, religiosity, and family relation (Rerkklang, 2013, 2017). The research results of this study will be useful to adapt to formulate policy and strategies for promoting sustainability development of Thai society and also for promoting sustainability development consciousness and behavior of Thai citizens.

\section{LITERATURE REVIEW}

\section{The Concept of Sustainable Development}

The definition of Sustainable Development by UN. United Nations defined sustainable development as "a process of change in which the exploitation of resources, the direction of investments, the orientation of technological development, and institutional change are all in harmony and enhance both current and future potential to meet human needs and aspirations".

\section{Three Pillars of Sustainability Development}

The three pillars of sustainability development are an important concept for practice. The concept of three pillars of sustainability development consists of at least the economic, social, and environmental pillars. If any one of the pillars is weak, the whole system is unsustainable (Thwink, 2014).

\section{Quality of Life or Well-being}

Quality of life or human well-being is a core goal of development but it cannot be directly observed or directly measured. Furthermore, many terms are often used interchangeably with well-being, such as quality of life, welfare, living well, living standards, utility, life satisfaction, prosperity, needs fulfilment, development, empowerment, capability expansion, human development, poverty, human poverty, land and, more recently, happiness (McGillivray \& Clarke, 2006).

This research will measure quality of life or well-being by adapted tool named the World Health Organization- Five Well-Being Index (WHO-5). The questionnaire is a short self-reported measure of current mental well-being (WHO, 1998; Child Outcomes Research Consortium, 2018).

\section{Happiness}

Happiness was promoted into public and globally by UN and has named 20th March 'the International Day of Happiness'. The UN encourages Member States to help counter unsustainable consumption patterns by elaborating measurements of happiness and economic well-being to better guide public policies.

The importance of happiness emerged in 1972 when the king of Bhutan, a small and poor but happy Himalayan kingdom, grew tired of countries being measured by their gross domestic product solely, and coined the term Gross National Happiness (GNH). Bhutan, a country with a very low GDP per capita, but ranked as the happiest nations in the world, started efforts to put happiness on the global agenda. The General Assembly today called on United Nations Member States to give more importance to happiness and well-being in determining how to achieve and measure social and economic development.

The World Happiness Report showed that where happiness is measured by how happy people are with their lives, the happiest countries in the world are all Northern European, scoring well both on wealth and political freedom, strong social networks, and an absence of corruption. The three latter factors together proved more important than income in explaining well-being differences between the top and the bottom countries.

World Happiness Report 2017 found that Norway topped the global happiness rankings for 2017, followed by Denmark, Iceland, and Switzerland. All of the top four countries rank highly on all the main factors found to support happiness: caring, freedom, generosity, honesty, health, income, and good governance. According to the report, Thailand was ranked no. 32 of the world which scored 6.424 (Helliwell, Huang, \& Wang, 2017). One of the popular tools to measure happiness is The Oxford Happiness Questionnaire. The Questionnaire was developed by psychologists 
Michael Argyle and Peter Hills at Oxford University. The Questionnaire is composed of 29 items with 6-point Likert Scale ranging from 1 = strongly disagree, $2=$ moderately disagree, $3=$ slightly disagree, $4=$ slightly agree, $5=$ moderately agree, and $6=$ strongly agree. This research had adapted The Oxford Happiness Questionnaire to 20 items with 5-point Likert Scale (The Ministry of Happiness, 2011).

\section{Previous Studies}

Rerkklang (2017) studied the factors for promoting and developing well-being and happiness of the elder Thai citizens. The sample of the survey was 500 Thai elders in Bangkok and metropolitans, 4 focus groups with Thai elders, and 30 In-depth interviews with Thai elders. Research result found there was statistically significant correlation between quality of life and mental health, community satisfaction, family relation, religiosity, physical health, social relation and government welfare, respectively. Happiness has a statistically significant correlation with quality of life, mental health, religiosity, family relation, social relation, physical health, and government welfare, respectively.

Rerkklang (2018) studied the effects of media on Thais' perceptions, consciousness, and performances on sustainability development. The objectives of research are: (1) to study Thais' sustainability development information exposure, seeking, sharing, posting, and commenting through digital media, mass media, and interpersonal media. (2) to study Thais' sustainability development perception on awareness, meaning, and goals. (3) to study Thais' sustainability development consciousness and behaviors. Data were collected by using questionnaire from 406 samples of Thai people. Data were analyzed for conclusion and testing hypothesis by computer program. Research results found that (1) There was statistically significant low correlation between sustainability development information exposure, seeking, sharing, posting, and giving comments through totally media, sustainability development perception and behavior but no statistically significant correlation between sustainability development information exposure, seeking, sharing, posting, and giving comments through media and sustainability development consciousness. (2) There was statistically significant low correlation between sustainability development perception and consciousness but moderate statistically significant correlation with sustainability development behavior. (3) There were statistically signific-

ant high correlation between sustainability development consciousness and behavior.

Maichum, Parichatnon, and Peng (2016) studied applica- tion of the extended theory of planned behavior model to investigate purchase intention of green products among Thai consumers. The research investigated 483 Thai consumers who were aged over 18 years, and highly educated with at least high school education, on purchase intention for green products by using an extended framework of the Theory of Planned Behavior (TPB) using structural equation modeling for analyzed data. The findings indicated that consumer attitude, subjective norm, and perceived behavioral control have significant positive influences on the purchase intention for green products. Environmental concerns have a significant effect on attitude, perceived behavioral control, and purchase intention for green products, but subjective norm. Moreover, environmental knowledge had no significant effect on the purchase intention for green products. But it had indirect effect through attitude towards purchasing green products, subjective norm, and perceived behavioral control. The findings from this study contribute to improving the understanding of intention to purchase green products, which could play a major role towards sustainable consumption.

Olsson (2014) studied Young People's 'Sustainability Consciousness' with student. Purpose of the study was to investigate the effects of the implementation of ESD in the Swedish school system by students' SC. The result in the two studies is that there are small differences between students in ESD-schools and REF-schools. The results in both reveal that there are differences between genders. These gender differences are worth considering in further research and ESD implementation.

\section{Research Hypotheses}

The research hypotheses were as follows:

H1: Sustainability development perception was statistically and significantly different by gender, education, career, income, and marital status.

H2: Sustainability development consciousness was statistically and significantly different by gender, education, career, income, marital status, and sustainability development perception.

H3: Sustainability development behavior was statistically and significantly different by gender, education, career, income, and marital status.

H4: Sufficiency economy behavior was statistically and significantly different by gender, education, career, income, marital status, and sustainability development perception.

H5: Religiosity was statistically and significantly different by gender, education, career, income, marital status, and sustainability development perception. 
H6: Family relation was statistically and significantly different by gender, education, career, income, marital status, and sustainability development perception.

H7: Quality of life was statistically and significantly different by gender, education, career, income, marital status, and sustainability development perception.

H8: Happiness was statistically and significantly different by gender, education, career, income, marital status, and sustainability development perception.

H9: There was a statistically significant positive correlation among sustainability development perception, consciousness, behavior, sufficiency economy behavior, religiosity, family relation, quality of life, and happiness.

H10: Sustainability development consciousness and sustainability development behavior have effect on quality of life and happiness.

H11: Sustainability development consciousness and sustainability development behavior have effect on quality of life and happiness with control effect of sustainability de- velopment perception, sufficiency economy behavior, religiosity, and family relation.

\section{RESEARCH METHODOLOGY}

\section{Research Design}

This study used survey research methodology.

\section{The Variables}

The research study has the variables as below:

The independent variables were gender, education, career, income, and marital status. The moderate variables were sustainability development perceptions, sustainability development consciousness, sustainability development behavior, sufficiency economy behavior, religiosity, and family relationship.

The dependent variables were quality of life and happiness.

\section{Conceptual Framework}

Based on literature and previous research, this research designed conceptual framework as below:

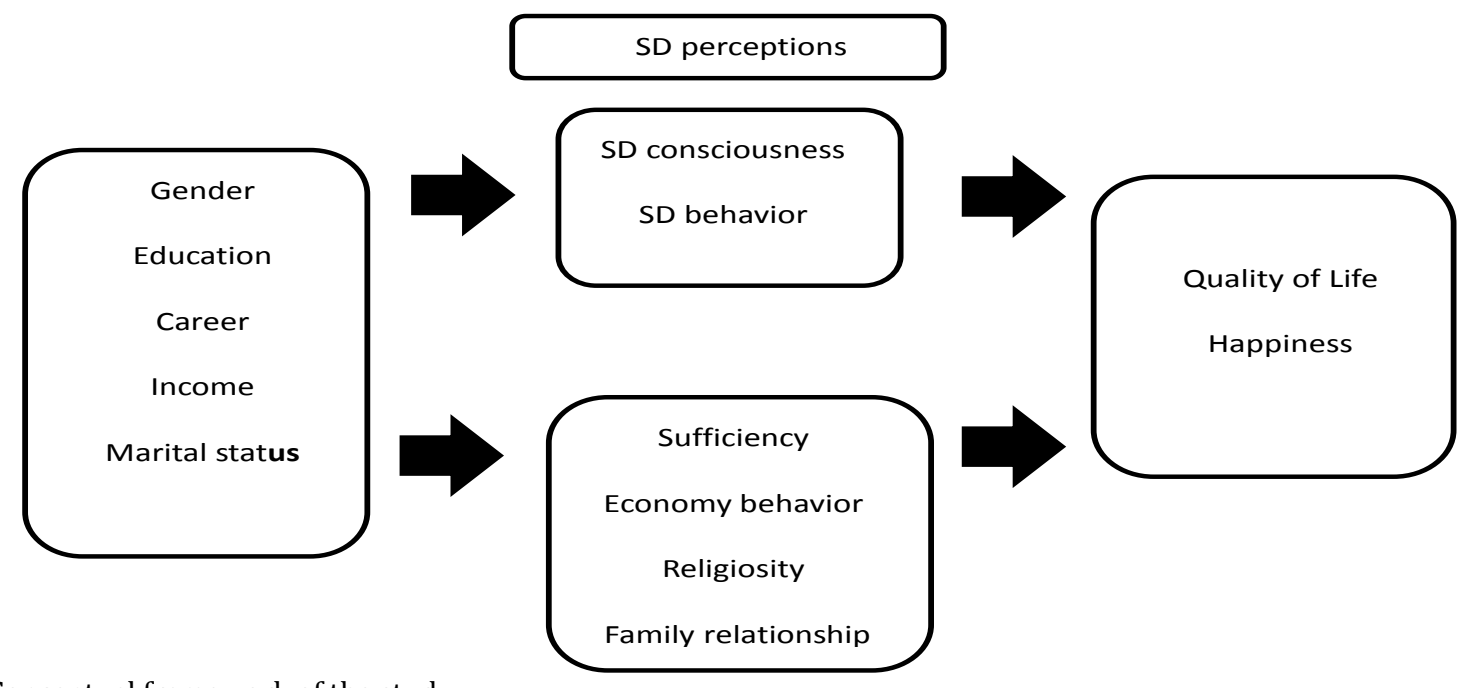

FIGURE 1. Conceptual framework of the study

\section{Population and Sample}

This research used survey design to study Thais nationwide. The sample was composed of 1,517 Thais from 5 regions which were Bangkok, central, eastern, northern, and southern. The sample was sampled by proportional quota.

\section{Measurement}

Measurement variables used in this study were either selected or modified from previous studies. First, sustainability development consciousness and behavior were developed by researcher which were composed of three subsets of SD as economy, social, and environment. Sufficiency Behavior was measured by 16-point Likert Scale which was created by researcher from sufficiency economic philosophy. Religiosity was measured by 17-point Likert Scale which was constructed by researcher based on Buddhism Doctrine. Family relationship was measured by 11-point Likert scale which was constructed by researcher based on the theory of relationship in family. Quality of life was measured by an adapted scale from The World Health Organization- Five Well-Being Index (WHO-5). Happiness was measured by a 25 -item questionnaire which was adapted from The Oxford Happiness Questionnaire original having 29 items. 


\section{Research Tools}

Research data were collected through questionnaires which were self-administered. The Questionnaire was composed of 6 parts which were demography and sustainability development perception, sustainability development consciousness, sustainability development behavior, sufficiency economy behavior, Family Relation, Quality of Life, and Happiness.

\section{Reliability Testing}

In this research, Cronbach's alpha was used to analyze the internal consistency of the questionnaire. The results of Cronbach's alpha coefficient were interpreted for meaning by using criteria which are showed by (Stephanie, 2014) citing (Tavakol \& Dennick, 2011) as shown in Table 1 below:

TABLE 1. Reliability of the Questionnaires

\begin{tabular}{llll}
\hline \hline & Number of Questions & Cronbach's Alpha & Level of Reliability \\
\hline \hline SD Consciousness & 16 & .928 & Excellent \\
SD Behavior & 17 & .919 & Excellent \\
Sufficiency Economy behavior & 16 & .879 & Good \\
Religiosity & 17 & .932 & Excellent \\
Family Relation & 11 & .947 & Excellent \\
Quality of Life & 5 & .917 & Excellent \\
Happiness & 20 & .953 & Excellent \\
\hline \hline
\end{tabular}

\section{The Data Analysis}

The statistical package for social sciences was used for analyzing preliminary results and testing hypotheses. The data were analyzed by the use of SPSS. Demographic characteristics were summarized using frequencies and percentages. Hypotheses were analyzed by inference statistics consisting of $t$-test, One-way ANOVA, Pearson product moment correlation, MANOVA, and MANCOVA.

\section{FINDINGS}

Research results found as following:

Thais were moderate level in sustainability development perception and religiosity but high level in sustainability development consciousness, sustainability development behavior, sufficiency economy behavior, family relation, quality of life, and happiness. Almost $72.9 \%$ of Thai people used to know about sustainability development. Research results about sustainability development consciousness found that Thais had high level in sustainability consciousness in total and economic but had highest level in social and environment. Thais had high level in sustainable behavior in total, economy, social, and environment.

The results are shown in the Table 2 below:

TABLE 2. Descriptive statistics of the variables

\begin{tabular}{llll}
\hline \hline Variables & Mean & Standard Deviation & Meaning \\
\hline \hline SD perception & 3.1297 & 1.52851 & Moderate \\
SD Consciousness in economy & 4.1047 & .65640 & High \\
SD Consciousness in social & 4.2181 & .67262 & Highest \\
SD Consciousness in ecology & 3.5374 & .58534 & High \\
Total SD Consciousness & 4.1891 & .60667 & High \\
SD behavior in economy & 3.5210 & .74807 & High \\
SD behavior in social & 3.7438 & .64781 & High \\
SD behavior in ecology & 3.7715 & .67809 & High \\
Total SD Behavior & 3.6759 & .61386 & High \\
Sufficiency Economy Behavior & 3.8730 & .50074 & High \\
Religiosity & 3.3675 & .78004 & Moderate \\
Family Relation & 4.0929 & .64249 & High \\
Quality of Life & 3.5892 & .87136 & High \\
Happiness & 3.9106 & .60704 & High \\
\hline \hline
\end{tabular}


Using inferences statistic for testing research hypotheses, we found the following:

1. There was a statistically significant difference in the level of sustainability development perception among Thais who were different in age, education, and career.

2.There was a statistically significant difference in the level of sustainability development consciousness among Thais who were different in education, career, income, and sustainability development perception.

3. There was a statistically significant difference in the level of sustainability development behavior among Thais who were different in age, education, career, income, marital status, and sustainability development perception.

4. There was a statistically significant difference in the level of sufficiency economy behavior among Thais who were di- fferent in age, education, career, income, marital status, and sustainability development perception.

5. There was a statistically significant difference in the level of religiosity among Thais who were different in gender, age, education, career, income, marital status, and sustainability development perception.

6. There was a statistically significant difference in the level of family relation among Thais who were different in gender, education, income, marital status, and sustainability development perception.

7. There was a statistically significant difference in the level of quality of life among Thais who were different in career, marital status, and sustainability development perception.

8. There was a statistically significant difference in the level of happiness among Thais who were different in age, education, and sustainability development perception.

The results are shown in Table 3 .

TABLE 3. $t$-test and $F$-test coefficient

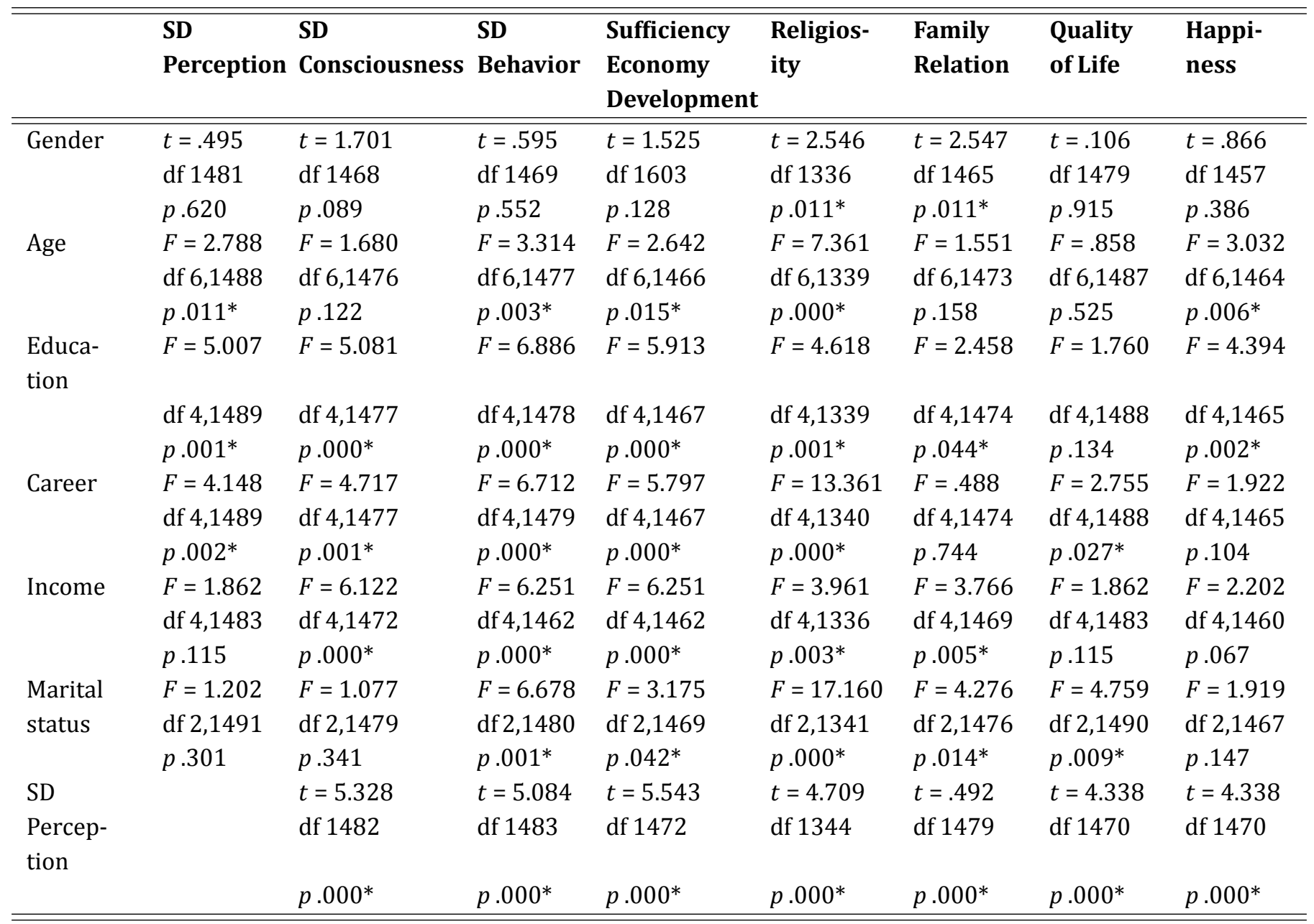

${ }^{*} p<0.05$ 
9. There were statistically significant positive correlations between SD perception, SD consciousness, SD behavior, suf- ficiency economy behavior, religiosity, family relation, quality of life, and happiness as shown in Table 4.

TABLE 4. Pearson correlation matrix among sustainability consciousness, sustainable behavior, sufficiency economy behavior, religiosity, family relationship, quality of life, and happiness

\begin{tabular}{|c|c|c|c|c|c|c|c|c|}
\hline & $\begin{array}{l}\text { SD } \\
\text { Perception }\end{array}$ & $\begin{array}{l}\text { SD } \\
\text { Consciousness }\end{array}$ & $\begin{array}{l}\text { SD } \\
\text { Behavior }\end{array}$ & $\begin{array}{l}\text { Sufficiency } \\
\text { Economy } \\
\text { Development }\end{array}$ & $\begin{array}{l}\text { Religios- } \\
\text { ity }\end{array}$ & $\begin{array}{l}\text { Family } \\
\text { Relation }\end{array}$ & $\begin{array}{l}\text { Quality } \\
\text { of Life }\end{array}$ & $\begin{array}{l}\text { Happi- } \\
\text { ness }\end{array}$ \\
\hline $\begin{array}{l}\text { SD } \\
\text { perception }\end{array}$ & - & $2.150^{* *}$ & ".130** & $\frac{142^{* *}}{.12}$ & $\frac{147^{* *}}{.14}$ & .123** & $.103^{* *}$ & . $.101^{* *}$ \\
\hline $\begin{array}{l}\text { SD } \\
\text { consciousness }\end{array}$ & & - & $.317^{* *}$ & $.459^{* *}$ & $.145^{* *}$ & $.413^{* *}$ & $.179^{* *}$ & $.259^{* *}$ \\
\hline $\begin{array}{l}\text { SD } \\
\text { behavior }\end{array}$ & & & - & $.720^{* *}$ & $.560^{* *}$ & $.380^{* *}$ & $.491^{* *}$ & $.519^{* *}$ \\
\hline $\begin{array}{l}\text { Sufficiency } \\
\text { economy } \\
\text { behavior }\end{array}$ & & & & - & $.497^{* *}$ & $.502^{* *}$ & $.500^{* *}$ & $.550^{* *}$ \\
\hline Religiosity & & & & & - & $.329 * *$ & $.467^{* *}$ & $.425^{* *}$ \\
\hline $\begin{array}{l}\text { Family rela- } \\
\text { tionship }\end{array}$ & & & & & & - & $.449^{* *}$ & $.519^{* *}$ \\
\hline $\begin{array}{l}\text { Quality of } \\
\text { life }\end{array}$ & & & & & & & - & $.727^{* *}$ \\
\hline Happiness & & & & & & & & - \\
\hline
\end{tabular}

10. Using MANOVA testing found that sustainability development behavior was statistically significant on quality of life and happiness (Wilks' lamda $F=7.724 p$.000) but sustainability development consciousness was not significant on quality of life and happiness (Wilks' lamda $F=2.255 p$ .105) and the interaction effect of sustainability development behavior and sustainability development consciousness was not statistically significant on quality of life and happiness (Wilks' lamda $F=2.910 p$.055).

11. The MANCOVA was used to examine the effect of sustainable development behavior as independent Variables (IVs), perception of sustainability development, sufficiency economy behavior, and religiosity, family relation as Covariates (COVs), and quality of life and happiness as dependent Variables (DVs). It showed statistically significant effect of sustainability development behavior (Wilks' lamda $F=$ 6.288 p .002), sufficiency economy behavior (Wilks' lamda $F=3.099 p .045$ ), religiousity (Wilks' lamda $F=15.549 p$ .000 ), family relation (Wilks' lamda $F=7.642 p .000$ ), and sustainability development perception (Wilks' lamda $F=$ $11.527 p .000$ ) on the quality of life and happiness.

\section{DISCUSSION AND CONCLUSION}

\section{Discussion}

The research found most of Thai people (73.9\%) have heard about sustainability development but the perception (had heard and channel of have heard) is only at a moderate level. The government and development agent must be urgently increased in promoting sustainability development perception, consciousness, and behavior moreover. This study also showed that Thais have a high level of happiness which supported the World Happiness Report 2017. Helliwell et al. (2017) found that Thailand was ranked no. 32 of the happiest nations in the world which scored 32 (6.424).

The results of the study showed that there were statistically significant positive correlations between sustainability development consciousness, sustainable development behavior, sufficiency economy behavior, religiosity, family relationship, quality of life, and happiness. Including, there was a statistically significant effect of sustainable development behavior on the quality of life and happiness. The research result indicated that the concept in sustainability development can create both well-being or quality of life and happiness. Consistent with the previous study of Rerkklang (2018), we also found the same that there was a statistically 
significant correlation between sustainability development perception, consciousness, and behavior. Also, there was a statistically significant high correlation between sustainability development consciousness and behavior. This research results also supported (Rerkklang, 2017) who found that there was a highly positive relationship between mental health and quality of life, happiness and life satisfaction of Thai elders, well-being or quality of life and Buddhism spirituality and satisfaction in family relationship.

\section{Conclusion}

This study aimed to investigate sustainability development perception, consciousness, behavior, and the effects on the quality of life and happiness. Besides, to study the correlation between sustainability development perceptions, consciousness, behavior, including sufficiency economy behavior, religiosity, family relation, quality of life, and happiness. Including, to study the effects of other variables, such as sufficiency economy behavior, religiosity, and family relation, on the quality of life and happiness.

Data were collected by self-administered questionnaire from 1517 Thais in five regions which were composed of Bangkok, Central, Northern, Eastern, and Southern. Research results found that sustainability development perception had effects on sustainable development consciousness and behavior, sufficiency economy behavior, religiosity, and family relation on quality of life and happiness. There is a positive correlation between all variables. Sustainability development behavior has an effect on quality of life and happiness with control effect of sustainability development perception sufficiency economy behavior, religiosity, and family relation.

\section{Suggestions}

Based on the findings of this study, the following suggestions are provided that Thai government, business, and education organizations should collaborate in promoting sustainability development perception, consciousness, and behavior on to all Thais, at every level, such as government officers, employee of business, urban and local community, media, and educational institutes.

\section{LIMITATIONS AND RECOMMENDATIONS}

This study has some limitations. The research design chosen might affect the reliability of the findings. Therefore, further research should retest this finding with various samples by using mixed methodology. Besides, the future research should use structural equation model to test the causes and effects of society's sustainability development and create sustainability development model. Further, the new research should study other independent variables that will be the causes of sustainability development perception, consciousness, and behavior.

\section{ACKNOWLEDGMENTS}

The authors would like to express gratitude to National Research Council of Thailand for support grants of this research.

\section{REFERENCES}

Child Outcomes Research Consortium. (2018). The world health organisation- Five well-being Index (WHO-5). Brunswick Place, London. Retrieved from https://bit. ly/2L4irTW

Helliwell, J. F., Huang, H., \& Wang, S. (2017). World happiness report 2017 (Tech. Rep.). New York City, NY: Sustainable Development Solutions Network.

Maichum, K., Parichatnon, S., \& Peng, K.-C. (2016). Application of the extended theory of planned behavior model to investigate purchase intention of green products among thai consumers. Sustainability, 8(10), 1077-1097. doi:https:// doi.org/10.3390/su8101077

McGillivray, M., \& Clarke, M. (2006). Understanding human well-being. Tokyo, Japan: United Nations University Press.

Olsson, D. (2014). Young people's "sustainability consciousness": Effects of esd implementation in Swedish schools (Doctoral dissertation). Department of Environmental and Life Sciences, Karlstads Universitet, Karlstad, Sweden.

Pathumporn, J., \& Nakapaksin, S. (2015). Participatory action research model for sustainable community based tourism development. International Journal of Business and Administrative Studies, 1(3), 89- 93. doi:https://doi.org/10.20469/ ijbas.10002-3

Rerkklang, P. (2013). The effect of information seeking about Dhamma, Buddhist practices and sufficiency economy practices on the happiness of Bangkok people (Unpublished thesis). Communication Arts and Innovation Management, National Institution Development Administration, Bangkok, Thailand.

Rerkklang, P. (2017). The factors for promotion and develop well-being and happiness of the elder Thais citizens (Unpublished thesis). Communication Arts and Innovation Management, National Institution Development Administration, 
Bangkok, Thailand.

Rerkklang, P. (2018). The effects of media on Thais' perceptions, consciousness and performances on sustainability development (Unpublished thesis). Communication Arts and Innovation Management, National Institution Development Administration, Bangkok, Thailand.

Rex, O. O., Yetunde, O., Grace, E. C., \& Pearl, O. A. (2017). Sustainable urbanization: Investigating problems encountered in uncontrolled urban growth in Nyanya - A suburb of Abuja, Nigeria. International Journal of Humanities, Arts and Social Sciences, 3(1), 13-19. doi:https://doi.org/10.20469/ijhss.3.20003-1

Stephanie. (2014). Cronbach's alpha: Simple definition, use and interpretation. Retrieved from https://bit . 1y/2La8aSM

Tavakol, M., \& Dennick, R. (2011). Making sense of cronbach's alpha. International Journal of Medical Education, 2, $53-55$. doi:https://doi.org/10.5116/ijme.4dfb.8dfd

The Government Public Relations Department. (2016). 12th national economic and social development plan. Bangkok, Thailand. Retrieved from https://bit.1y/2mdIie4

The Ministry of Happiness. (2011). The oxford happiness inventory. Retrieved from https://bit . ly/2NIWc41

Thwink. (2014). The three pillars of sustainability. Retrieved from https://bit.1y/1PpAg8V

WHO. (1998). Who (five) well-being index (1998 version). Hillerød, Denmark: The WHO-5. 